\title{
Kulturna in jezikovna raznolikost
}

Ko smo pred nekaj leti v Sloveniji znova poskusili uveljaviti jezikovno razsodišče, se je dvignil plaz nasprotovanj. Nihče ne bo odločal o tem, kaj je prav in kaj ni prav v jezikovni rabi. Jezik obstaja med ljudmi in je last vseh ljudi, meni lingvist Ferdinand de Saussure. In vendar, jezik je mogoče bolj ali manj obvladovati in $k$ temu lahko pripomore tudi jezikovno razsodišče, predvsem pa družba, v kateri živimo, socialno okolje, kultura, ki ji pripadamo. Jezik je odvisen predvsem od družbenega zaledja. Povezan je tudi z razvojem mišljenja, tako tesno, da lingvisti še vedno ne vedo, ali je treba najprej obvladati jezik, da lahko mislimo, ali pa se misel oblikuje v jeziku.

Zakaj ljudje različno obvladamo jezik? Zakaj se dogaja, da je tudi po dolgih letih šolanja besedni zaklad siromašen, in da celo iz šol prihajajo funkcionalno nepismeni, torej jezikovno in pojmovno slabo podkovani mladi ljudje? Z jezikom je povezana tudi socializacija, ta pa ne poteka zgolj v šoli, marveč tudi drugje, pogosto v vrstniških skupinah in na območjih marginalizacije, kot so ulice, trgi itd. Od socializacije je odvisna govorna razvitost, s slednjo pa je povezan tudi kognitivni razvoj.

Z jezikom je tesno povezana pismenost. Ta se zrcali $v$ zmožnosti uporabljati jezik, predvsem $v$ zmožnosti pisnega razumevanja in sporočanja, pa tudi v razumevanja različnih družbenih diskurzov: etatističnega, novinarskega, filozofskega, političnega ipd. Funkcionalna nepismenost je pogosto posledica družbene razslojenosti. Pripadnikom različnih družbenih slojev so namreč pisni viri različno dostopni. Pripadniki najnižjih družbenih slojev so največkrat sposobni uporabljati le jezik "svoje skupnostiø, pri-
UVODNIK

padniki srednjih slojev pa jezik njihove skupnosti, ki je za nameček še formaliziran, standarden. Pri tem ne gre za slovnični sistem, narečni sistem ne za žargon, temveč za različno uporabo slovničnih struktur in besedišča. Formalizirani, standardni jezik vsebuje tudi precej več pridevnikov, glagolov, brezosebnih struktur, veznikov in odvisnih stavkov. Funkcionalno nepismeni ljudje navadno govorijo o preprostih vsakdanjih, ponavljajočih se temah. Uporabljajo manj glagolov, pridevnikov, najpogosteje predvsem premi govor, pa tudi manj zahtevne pojme.

Govorec, ki uporablja le »jezik svoje skupnosti $\ll$, je odvisen od okoliščin, govorec, ki obvlada formalizirani jezik, pa je razmeroma neodvisen od njih. Omejen jezik le delno izraža pomen, razvit jezik pa govorcu omogoča, da se posveti posploševanju, da uvidi zakonitosti.

"Jezik skupnosti« uporabljajo skupine, ki se med seboj dobro poznajo in katerih člani zadeve poznajo in jih ne razlagajo. Take skupine imajo razvit občutek solidarnosti, pripadnosti. Standardni, formalizirani jezik pa srečujemo, kadar zadeve niso znane vnaprej, kadar je namesto skupnosti v ospredju govorčeva individualnost. Funkcionalno pismena oseba zna uporabljati sjezik svoje skupnosti« in formalizirani jezik. To pomeni, da je v okviru materinščine večjezična, saj obvladuje različne ravnine jezika, to pa ji tudi odpira vrata v različna socialna okolja in skupine.

Za človeštvo je bolje, da se znanje pretaka svobodno, kot da se mu na pot postavljajo ovire, denimo neznanje jezikov. Po Aristotelu je človek mimetično bitje, ki se uči s posnemanjem. Učimo se 
tudi s posnemanjem tujih izkušenj in kultur. »Ljudje se tako zelo razlikujejo med seboj zato, ker so sprva posnemali drug drugega in ker to še zmeraj neprestano počno, je menil Etienne Bonot de Condillac že v 18. st. Posnemanje ne bi bilo mogoče in učinkovito brez znanja tujih jezikov. $\breve{C}$ e bo povsod prevladala angleščina kot sjezik okolja«, na televiziji, v kinu, časopisih, če bo prodirala v naš miselni svet s (slabimi) prevodi, tudi v posnemanju ne bomo več svobodni. Omejena bo tudi naša pravica do izražanja.

Prevlada ameriških konceptov jezika in hkrati pomanjkanje jezikovne ter kulturne raznolikosti sta očitna tudi v slovenskem jeziku in izobraževanju odraslih. Oddelki v podjetjih so se spremenili $v$ divizije, zakoni se več ne izvajajo, marveč implementirajo, informacije se več ne širijo, marveč jih je mogoče diseminirati. Nezadostna sporočilnost $v$ tujem jeziku ali nepoznavanje jezika lahko seveda naredita sporočilo nerazumljivo. To je najočitnejše pri prevodu reklam. "Z njo sva eno« se glasi prevod francoske reklame. Zraven avtomobila, ki je v francoščini ženskega spola, stoji moški. Presenečeni mimoidoči pa na sliki iščejo žensko, ki je seveda ni ...

Tudi izobraževanje postaja vse bolj standardizirano. Sodelovanje v timu povsod ponazarjajo z enakimi igrami, sestavljankami, moralne dileme pa povsod prikazujejo z enako zgodbo. Predavanja so tudi velikokrat strukturirana po ameriškem vzorcu. "Pritegnite pozornost poslušalstva z anekdoto ipd., povejte, kaj boste povedali, povejte, kar želite povedati, in povejte, kaj ste povedali, zahvalite se občinstvu« so navodila, $k i$ smo jih deležni ne glede na to, kje se izobražujemo. Vse več podjetij je pripravljenih vložiti denar $v$ usposabljanje za komuniciranje (komunikacijski treningi), ki pa povsem prezre psihološko in družbeno raven sporazumevanja v posameznem kulturnem okolju.

Stranski učinek tehnološke in ekonomske globalizacije je tudi vizija globalne kulture, ki bi se izražala v enem samem jeziku. Evropa ima štirideset in še več kulturnih identitet, ki se izražajo v prav toliko jezikih, imajo različno preteklost in tradicijo, vse skupaj pa povezujeta skupna zemljepisna in zgodovinska paradigma ter skupen spomin. Tako se spričo ekonomske globalizacije v Evropo vraěa kulturni etnocentrizem, hkrati pa so v Evropi zmeraj bolj zaskrbljeni nad prevlado ameriške angleščine. Narod, ki je ekonomsko najmočnejšsi, prevladuje tudi pojmovno, Njegov pogled na svet, njegovo prikazovanje resničnosti, ki se zrcali v njegovem jeziku, počasi nadvlada nad drugimi, jim narekuje vrednote, način mišljenja, ideale, prepričanje, soustvarja in spreminja njihove navade ter njihovo obnašanje. Skratka, spreminja ali negira njihovo kulturo. Te težnje so tako močne, da v zadnjem času o tej tako imenovani svetovni kulturi govorijo kar kot o kulturi McWorld. Zanjo je značilno, da ne upošteva kulturne in jezikovne raznolikosti drugih okolij. Gre pravzaprav za univerzalno kulturo potrošništva, ki jo narekujejo večnacionalna podjetja in ki s svojimi sporočili, slogani, televizijskimi reklamami, iztrganimi iz pojmovnega sveta posameznih kultur, globoko posega $v$ socialne razsežnosti teh okolij. Tega se v Evropi zavedajo, zato skusajo tudi dohiteti Američane. Če ne bodo ponudili dovolj izobraževalnih programov na daljavo $v$ različnih evropskih jezikih, bo ščasoma zamrlo bogastvo evropske kulturne, družbene, politične in gospodarske raznolikosti, s tem pa tudi ustvarjalnost, ki jo poraja raznolikost.

Čas je torej, da razmislimo o pomenu lastnega jezika za utrjevanje in razvoj naše identitete. Težko se bomo globalizirali, če se ne zavedamo dovolj dobro, od kod prihajamo in kdo smo postali, če ne bomo poznali tančin lastnega jezika in lastne kulture. Čas je tudi, da razmislimo o tem, da potrebujemo jezikovno politiko, ki bi z usklajenimi postopki spodbujala rabo evropskih in drugih jezikov, stem pa tudi napajanje s kulturno raznolikostjo različnih celin.

\section{Dušana Findeisen}

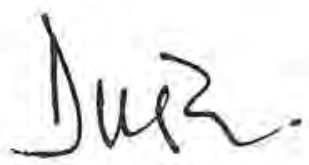

